\title{
PENERAPAN PRINSIP HIGIENE SANITASI WARUNG MAKAN DI PASAR CIK PUAN PEKANBARU
}

\author{
Nila Puspita Sari ${ }^{1}$, Makomulamin ${ }^{2}$ \\ Prodi Kesehatan Masyarakat Program Sarjana \\ STIKes Hang Tuah Pekanbaru \\ nps@htp.ac.id ${ }^{1}$, makomul_amin@htp.ac.id ${ }^{2}$
}

\begin{abstract}
Food is a source of energy and nutrients and can be a source of microorganisms and bacterial growth. Prevention of damage and diseases due to food done through the action of the application of sanitary higiene towards referring to Permenkes no. 1096 / menkes / per / vi / 2011, ranging from the food, storage, food processing, equipment, food storage so and the presentation of food .This research aims to review the application of sanitary higiene food in Cik Puan's Market Pekanbaru. The research is descriptive qualitative research.This study conducted at food stalls of Cik Puan's Market Pekanbaru. The informants are 8 the stall owners eat the cik puan pekanbaru .Data collection by conducting interviews and observations. Data analyzed used triangulation data. Research results in food stalls in the cik puan Pekanbaru, we can see that the raw food, processing food, Processing food, and the presentation of food in 8 food stalls in the cik puan pekanbaru sanitation food higiene have met the requirements, while storage raw material, cooking utensils and eat, and food storage that is discovered yet qualified.It is hoped that the market operators can provide socialize higiene sanitation stall owners in the cik puan pekanbaru
\end{abstract}

Keyword

: Higiene Sanitation, Food Stalls, Pekanbaru

\begin{abstract}
ABSTRAK
Makanan yang sehat merupakan kunci untuk terciptanya suatu keamanan pangan, salah satunya di warung makan. Penelitian ini bertujuan untuk mengetahui higiene sanitasi makanan di warung makan Pasar Cik Puan Pekanbaru. Penelitian ini merupakan penelitian deskriptif kualitatif. Penelitian ini dilakukan di Warung Makan Pasar Cik Puan Pekanbaru. Informan dalam penelitian ini berjumlah 8 orang pemilik Warung Makan Pasar Cik Puan Pekanbaru. Variabel dalam penelitian ini meliputi pemilihan bahan mentah, penyimpanan bahan mentah, proses pengolahan makanan, peralatan masak dan makan, penyimpanan bahan makanan jadi, serta penyajian. Metode penelitian ini adalah deskriptif kualitatif. Analisis data menggunakan triangulasi data. Pengumpulan data dengan melakukan wawancara mendalam dan observasi. Hasil Penelitian pada warung makan di Pasar Cik Puan Pekanbaru, diketahui bahwa Pemilihan bahan makanan mentah, proses pengolahan makanan, dan penyajian makanan di 8 Warung Makan di Pasar Cik Puan Pekanbaru telah memenuhi persyaratan higiene sanitasi makanan, sedangkan penyimpanan bahan mentah, peralatan masak dan makan, serta penyimpanan bahan makanan jadi masih ditemukan belum memenuhi syarat. Diharapkan agar pengelola pasar dapat memberikan sosialisasi dan training terkait higiene sanitasi bagi pemilik warung di Pasar Cik Puan Pekanbaru.
\end{abstract}

Kata Kunci : Higiene Sanitasi, Warung Makan, Pekanbaru

\section{PENDAHULUAN}

Akses terhadap kecukupan jumlah makanan yang aman adalah kunci untuk menjaga keseimbangan hidup dan memperlihatkan kesehatan yang baik. Ketidakamanan pangan yang mengandung bakteri berbahaya, virus, parasite atau bahan kimia, dapat menyebabkan lebih dari 200 jenis penyakit (mulai dari diare hingga kanker). Diperkirakan sebanyak 600 juta jiwa atau 1 dari 10 orang di dunia, jatuh sakit setelah mengkonsumsi makanan yang tercemar dan 420.000 diantaranya meninggal dunia setiap tahunnya. (WHO, 2020) 
Di Indonesia program pengawasan makanan harus mendapat perhatian khusus karena keamanan pangan masih merupakan masalah dalam bidang pangan. Higiene dan sanitasi makanan merupakan pengendalian terhadap empat faktor makanan yaitu meliputi faktor tempat atau bangunan, peralatan makan, orang dan bahan makanan (Syahlan et al., 2018). Penyakit yang disebabkan oleh makanan salah satunya dikenal dengan keracunan makanan. Data BPOM tahun 2017 yang dilaporkan dari 34 $\mathrm{BB} / \mathrm{BPOM}$ di seluruh Indonesia sebanyak 53 kejadian luar biasa (KLB) keracunan pangan.

Tercatat jumlah orang yang dilaporkan terpapar sebanyak 5293 orang, sedangkan untuk kasus Kejadian Luar Biasa (KLB) keracunan pangan yang dilaporkan sebanyak 2041 orang sakit dan 3 orang meninggal dunia. Dilihat dari jenis pangan, penyebab dari Kejadian Luar Biasa (KLB) keracunan pangan tahun 2017 adalah masakan rumah tangga tercatat sebanyak 20 kejadian $(37,74 \%)$, pangan jajanan/siap saji berjumlah 6 kejadian $(11,32 \%)$, dan pangan olahan serta pangan jasa boga masing-masing berjumlah sebanyak 7 kejadian (13,21\%). Berbagai permasalahan kesehatan seperti diare, tifoid, hepatitis dapat muncul di masyarakat akibat adanya kontaminasi makanan.

Untuk mencegah terjadinya kontaminasi pada makanan perlu dilakukannya sanitasi terhadap makanan. Menjaga dan meningkatkan kualitas makanan penting untuk menghindari kontaminasi makanan yang dapat menjadi gangguan kesehatan masyarakat (Dakwani, 2019)

Menurut Mundiatun, dkk. (2015) sanitasi terhadap makanan bertujuan untuk mengurangi kerusakan pada makanan, menjamin keamanan pangan serta mencegah penyakit akibat pangan. Sanitasi makanan suatu upaya dalam pencegahan terjadinya kontaminasinya makanan dan memfokuskan suatu tindakan untuk membebaskan makanan dari bahaya yang dapat merusak kesehatan, dalam hal ini dimulai dari sebelum makanan diproduksi, proses pemilihan bahan makanan, penyimpanan bahan makanan, pengolahan makanan, pengangkutan makanan, sampai penyajian makanan.

Salah satu tempat pengolahan makanan yang harus diperhatikan yaitu warung makan. Hal ini dikarenakan rumah makan merupakan tempat untuk mengolah, menyediakan hingga menghidangkan untuk umum dan memiliki potensi untuk menyebakan terjadinya penyakit apabila tidak dikelola dengan baik (Yunus, 2015). Warung makan merupakan tempat penyediaan makanan dan minuman yang sehat, bergizi dan dengan harga yang terjangkau. Warung makan biasanya berada di lingkungan sekolah, kantor, pasar, kampus dan asrama yang melingkupi suatu instansi. Faktor risiko terjadinya keracunan makanan maupun penyakit yang diakibatkan makanan harus dihindari, maka selain cara pengolahan, tempat makan seperti restoran, warung, warung dan lain sebagainya merupakan hal penting yang harus diperhatikan, karena kondisi tempat penyediaan makanan bagi masyarakat harus bersih dan kualitas makanan, penyajian, makanan yang dijual dan peralatan makanan yang digunakan harus memenuhi syarat kesehatan.

Survei awal yang dilakukan pada 3 warung makan di Pasar Cik Puan Pekanbaru diketahui bahwa warung makan masih belum memperhatikan serta menerapkan enam prinsip higiene sanitasi pada makanan. Kondisi dapur masih tidak tertata rapi, serta belum terjaga kebersihannya. Hal ini dapat berpotensi menyadi factor risiko penyebab terjadinya penyakit yang disebabkan oleh makanan serta kontaminasi dari makanan. Serta belum ada ditemukan penelitian terkait higiene sanitasi pada makanan yang terkait oleh enam prinsip higiene pengolahan makanan di Pasar Cik Puan Pekanbaru. Tujuan penelitian ini adalah untuk Mengetahui higiene sanitasi pada warung makan di Pasar Cik Puan Pekanbaru. Berdasarkan hal tersebut, peneliti tertarik 
untuk melakukan penelitian tentang "Penerapan Prinsip Higiene Sanitasi Warung Makan di Pasar Cik Puan Pekanbaru"

\section{METODE}

Penelitian ini adalah penelitian deskriptif kualitatif untuk mengetahui gambaran higiene sanitasi pada warung makan yang ada di Pasar Cik Puan Pekanbaru. Penelitian ini dilakukan pada bulan April-September 2020. Subjek penelitian ini adalah 8 pemilik warung makan atau pengelola makanan yang ada di Pasar Cik Puan Pekanbaru.

Metode penelitian ini menggunakan deskriptif kualitatif. Analisis data dilakukan dengan cara triangulasi sumber, metode, dan data terhadap variabel penelitian yaitu pemilihan bahan mentah, penyimpanan bahan mentah, proses pengolahan makanan, peralatan masak dan makan, penyimpanan bahan makanan jadi, serta penyajian yang berpedoman kepada Permenkes No. 1096/ Menkes/Per/VI/2011. Data diperoleh dari wawancara mendalam dan observasi.

\section{HASIL}

\section{Pemilihan Bahan Makanan}

Terkait pemilihan bahan baku, seluruh pemilik warung berbelanja di Pasar Ci Puan dengan pemilihan bahan baku sesuai dengan kebutuhan masing-masing. Untuk bahan-bahan habis pakai biasanya para pemiliki warung berbelanja bahan-bahan setiap hari, sedangkan untuk bahan yang lainnya seperti indomie biasanya mereka belanja setiap seminggu sekali, dua minggu sekali, atau bahkan sebulan sekali tergantung lama habisnya bahan jualan. Hal ini dapat dilihat pada cuplikan berikut :

"belanja untuk jualan beli di pasar sini dek, untuk masak bahan yang baguslah"(Informan 1)

"kalo bahan-bahan belanja di pasar ni lah, barang secukup duitnya, yang murah-murah. Mie instan dak tiap hari do, seminggu sekali baru belanjo"'(Informan 2)

\section{Penyimpanan Bahan Makanan}

Bahan-bahan makanan yang dibeli oleh para pemilik warung dibawa pulang dan disimpan di lemari pendingin di rumah masing-masing. Kecuali untuk bahan baku seperti mie instan dan kopi serta minumanminuman sachet lainnya, biasanya langsung ditaruh atau ditata di etalase warung.

"Bahan mentah ya saya tarok di kulkas, sampai rumah bahan-bahan simpan di kulkas di rumah"(Informan 5)

"Belanjaan dari pasar disimpan di kulkas, untuk masak subuh nanti" (Informan 2)

\section{Pengolahan Bahan Makanan}

Pada saat dilakukan wawancara mendalam terhadap 8 informan, diketahui bahwa sebelum pengolahan bahan makanan, makanan dibersihkan dan cuci terlebih dahulu hingga bersih. Bumbubumbu ada yang menggunakan bumbu yang sudah dijual di pasar, ada yang menggiling sendiri, da nada juga yang menggunakan blender untuk menghaluskan bumbu-bumbu. Proses pengolahan makanan dilakukan di rumah masingmasing

"Kalo ibu sayur kayak buncis kayak apalah ya itu ibu bersihkan dulu baru dicuci, dikeringkan dulu baru di potongn kalo kayak wortel, buncis, jipan, kalo kayak sayur-sayur yang lain tu kadang dipotong dulu baru dicuci dulu. Paling kalo ibu nyuci sayur sekurangnya 3 kali, angkat dulukan kadang ada pasir-pasir dibuang airnya diangkat lagi, kalo ibu biasanya kayak gitu. Saya beli mie untuk lontong, kalo gak habis saya masak jadi mie goreng, kadang orang makan pakai nasi, pokoknya bahan pandai-pandai kita olah aja, sikit untuk habis hari itui" (Informan 1) 
"Sayur-sayur sebelum masak dibersihkan dulu lalu dicuci, biar bersihkan" (Informan 2)

"Ya kalo kami dek misalnya mengolah sayur kami cuci dulu baru kami potongpotong jadi kami kan nampak nanti tu, kalo aku sih misalnyakan sayur, habis aku potongkan nanti aku rendam, misalnya kayak sayuran tertentukan ada ulatnya, aku rendam pakai garam dulu, tukan ulat-ulatnya keluar bersih jadinya. Aku cuci 2 sampai 3 kali pakai air mengalir" (Informan 8)

\section{Peralatan Masak/Mengolah Makanan}

Menurut seluruh informan, peralatan yang digunakan untuk memasak dicuci terlebih dahulu sebelum digunakan. Sedangkan untuk peralatan yang tersedia di warung, sudah dibersihkan sehari sebelumnya dan dapat langsung digunakan kembali. Perkakas lainnya seperti piring, gelas, sendok dan garpu, serta teko dibersihkan di warung dan disimpan di etalase masing-masing warung, ada yang tertutup dan masih ada juga yang terbuka.

"Yalah dek, saya cuci dulu sebelum dipakai, kuali, gelas, piring-piring, apa lagi di tinggal di rak terbuka gini kan debu ya"(Informan 5)

"Peralatan masak lengkap, ya kalo mau dipakai ya dicuci dulu dek" (Informan 6)

\section{Penyimpanan Makanan Jadi}

Pada saat wawancara mendalam terhadap 3 informan, diketahui bahwa penyimpanan makanan yang telah jadi di letakkan di wadah yang tertutup di tempat lemari kaca untuk dipajang.

"Ya gitulah dek, lihat sendiri, diletak di wadah kayak gitu (wadah stainless)" (Informan 1)

"Kalo udah jadi? Langsung ke etalase itu, masukin ketempat apa, ya kayak wadah gitu, ya langsung kita pajang" (Informan 2)

"Oh ditempat-tempat gitu ya dek. Iya kita ada tempatnya, kalo biasanya kami makanan yang telah siap itu, kami sediakan tempat yang khusus ada tutupnya, jadi nanti kalo sudah tidak panas lagi masakan nya kami tutup gitu, jadi kami emang jagalah dari debu, ditutuplah ya"(Informan 3)

\section{Penyajian Makanan}

Penyajian makanan disajikan langsung oleh pemilik warung sendiri, baik itu untuk makan di tempat atau dibungkus dan dibawa pulang. Semua bahan-bahan makanan yang akan dijajakan sudah disusun di etalase masing-masing. Sebagian etalase memiliki kain penutup dan sebagian lagi tidak berpenutup.Saat pembeli datang, makanan langsung disiapkan dari masingmasing wadah lalu dihidangkan atau dibungkus untuk dibawa pulang konsumen.

"Ya kita yang sajikan dek, yang bungkus langsung dibungkus yang makan disini langsung disiapkan diatas piring" (Informan 1)

"kalo ada yang pesan kita yang ambilkan sesuai pesanan ada yang bungkus ada yang makan sini," (Informan 3)

\section{Penghasilan yang didapat dari menjual makanan di Warung.}

Seluruh informan menyampaikan bahwa semenjak pandemic Covid-19 penjualan mereka tidak seramai biasanya. informan, diketahui bahwa tidak disebutkan berapa jelas pendapatan perhari, tapi dari penjualan pada hari ini dapat mengembalikan modal harian yang dikeluarkan untuk membeli semua bahanbahan makanan yang dijual, tetapi ada 3 informan tidak mendapatkan keuntungan bahkan sampai tidak kembali modal.

"Kalau apa, omset gitu ngak tentu nak, kadang orang belanja keluar ya siapa yang mau belanja, mau hitung perbulan pun susah, tambah lagi jaman covid ni. Serba susahlah" (Informan 1)

"Aduh pertanyaan nya, ya kalo dapat banyak ya Alhamdulillah, kalo dapat sedikit ya gitu, kita syukuri aja dek, gak bisa juga dipastikan, dipatokkan ya.. 
InsyaAllah kembali modal. Tapi kalo kita berjualan ini emang gak bisa dipastikan untuk penghasilan nya dek" (Informan 3)

"Sekarang susah nak dipastikan, bisa belanja modal aja udah syukur. Tak seramai dulu memang, tapi masih ada yang belanja Alhamdulilah sekali."(Informan 4)

\section{Makanan Yang Tercemar Atau Tidak Bersih Dapat Menyebabkan Penyakit}

Seluruh informan mengetahui akibat makanan yang tidak bersih dan tercemar.

"Ya sakit perutlah, apa tu namanya diare ya, itulah nak harus pandaipandai jaga kebersihan” (Informan 3)

"Biasanya sakit perut ya, mencret gitu, tapi belum terjadi ya disini, jangan sampai" (Informan 6)

\section{PEMBAHASAN}

\section{Pemilihan Bahan Makanan}

Pemilihan bahan makanan mentah untuk pengadaan makanan di warung harus memperhatikan kualitas bahan makanan tersebut, agar tidak adanya kerusakan dari bahan makanan mentah. Berdasarkan hasil observasi yang dilakukan bahwa pemilihan bahan makanan pada 8 warung makan di Pasar Cik Puan Pekanbaru telah cukup baik dan memenuhi syarat. Pemilihan bahan makanan seperti ikan, ayam, daging, sayursayuran dalam keadaan segar dan tidak rusak, dapat dilihat dari segi fisik yang segar, tidak berbau busuk, serta layu. Bahan-bahan makanan mentah di warung dibeli setiap hari di pasar cik puan sesuai jumlah yang dibutuhkan untuk sehari memasak. Bahan-bahan makanan yang lain seperti mie instan, kecap, saus, tepung dan bahan-bahan kering lainnya selalu dilakukan pengecekkan waktu kadaluarsa sebelum membeli. Sehingga pada saat observasi dilakukan bahan-bahan kering tersebut dalam keadaan baik, tidak rusak dan tidak melewati waktu kadaluarsa.

Kualitas bahan makanan yang baik dilihat berdasarkan ciri-ciri fisik dan mutunya. Kualitas bahan makanan yang baik terbebas dari pencemaran maupun kerusakan. Penelitian ini sejalan dengan penelitian yang dilakukan oleh Reinanda (2018) di Dapur Umum Panti Asuhan Al Istiklal Kota Pekanbaru. Berdasarkan hasil observasi penelitian yang dilakukan bahwa pemilihan bahan makanan seperti ikan, sayur serta bumbu masakan sudah cukup baik. Bahan-bahan dilihat dari segi fisik dalam keadaan baik,segar, dan tidak berubah bentuk.

Penelitian di Gianyar, Bali juga ditemukan bahwa warung makan yang menyediakan menu sayur telah mengetahui cara memilih bahan makanan yang segar. Ciri-ciri sayuran yang segar yaitu warnanya hijau dan segar seperti baru dipetik, tidak layu atau berwarna kuning, daunnya sedikit robek dimakan ulat (bebas dari pestisida). (Kesuma, 2018).

Senada dengan penelitian Septiani (2020), pemilihan bahan makanan, penyimpanan bahan makanan, pengolahan bahan makanan, penyimpanan makanan jadi, pengangkutan hingga penyajian makanan diperoleh dari pemasok resmi dan terjamin kualitasnya. Pemilihan bahan berkualitas baik merupakan salah satu daya tarik kuliner (Rahmadiyanti, 2018).

Pemilihan bahan makanan di warung makan Pasar Cik Puan Pekanbaru sudah memenuhi syarat. Untuk menjaga kualitas dari bahan makanan, pihak warung harus selalu memperhatikan setiap pembelian atau pemilihan bahan makanan yang akan digunakan untuk penyediaan makanan.

Menurut Permenkes No.1096/ Menkes/Per/VI/2011 pemilihan bahan makanan mentah yang memenuhi syarat harus dalam keadaan segar, baik, tidak rusak dan sebaiknya berasal darin tempat resmi yang diawasi.

\section{Penyimpanan Bahan Makanan}

Kesalahan dalam penyimpanan bahan makanan mentah dapat berakibatkan penurunan mutu dan keamanan pangan. Maka bahan makanan mentah yang akan digunakan untuk proses produksi maupun 
pengolahan, baik itu bahan baku, bahan tambahan maupun bahan penolong harus disimpan dengan penyimpanan yang baik (Depkes RI, 2009).

Berdasarkan hasil observasi yang dilakukan peneliti dapat dilihat bahwa penyimpanan bahan makanan masih dalam keadaan yang tidak memenuhi syarat. Bahan makanan seperti sayur-sayuran tidak dibersihkan dahulu, penyimpanan langsung menggunakan plastik-plastik dari pasar. Sedangkan bahan makanan seperti ikan, ayam, dan daging disimpan didalam freezer langsung menggunakan plastik ditumpuk begitu saja dalam keadaan yang tidak dibersihkan terlebih dahulu. Kondisi tersebut dapat membuat tidak terjaganya mutu serta kesegaran dari bahan-bahan makanan tersebut. Bahan makanan kemasan seperti mie instan, minyak, telur, tepung, gula, dari 5 warung yang terlihat dibiarkan begitu saja terbuka sehingga dapat menyebabkan gangguan atau kontaminasi dari tikus dan binatang pengganggu lainnya. Sedangkan 3 warung yang lain tempat penyimpanan tepung, gula, minyak menggunakan wadah tertutup sebagai tempat penyimpanan bahan makanan kemasan.

Penelitian ini sejalan dengan penelitian yang dilakukan oleh Reinanda (2018) di Dapur Umum Panti Asuhan Al Istiklal Kota Pekanbaru. Berdasarkan observasi penelitian yang dilakukan bahwa penyimpanan bahan makanan seperti ikan, daging disimpan di dalam freezer, akan bercampur dengan bahan-bahan minuman atau minuman botol. Cabe maupun sayursayuran di simpan menumpuk dan padat didalam kulkas. Bahan sayuran tidak dicuci dan dipilah sebelum disimpan di kulkas, tetapi langsung disimpan dalam pastik sehingga membuat tidak terjaganya mutu dan kesegaran bahan makanan. Akibatnya bahan bahan makanan mentah tersebut mudah membusuk.

Penyimpanan bahan makanan di Warung Makan Pasar Cik Puan Pekanbaru belum memenuhi syarat sesuai dengan Permenkes No. 1096/Menkes/Per/VI/2011.
Untuk menjaga kesegaran dan mutu dari bahan makanan, pihak warung harus memperhatikan kebersihan, kerapian dan kesegaran bahan makanan yang disimpan untuk penyediaan makanan berikutnya, agar tidak terjadinya pembusukan pada bahan makanan yang disimpan dalam jangka waktu yang lama.

Berdasarkan Peraturan Menteri Kesehatan Nomor 1096/Menkes/ Per/VI/2011 penyimpanan bahan makanan yang memenuhi syarat harus terhindar dari adanya kontaminasi bakteri, tikus maupun binatang hama lainnya, penyimpanan bahan makanan juga perlu memperhatikan waktu kadaluarsa, sehingga bahan makanan yang mendekati kadaluarsa bisa digunakan dan dimanfaatkan lebih dulu. Penyimpanan bahan makanan juga harus memperhatian suhu seperti daging, ayam, ikan udang dalam waktu 3 hari atau kurang dari waktu 3 hari disimpan pada suhu $-5^{\circ} \mathrm{C}$ sedangkan sayuran, buah dan minuman disimpan pada suhu $10^{\circ} \mathrm{c}$ serta bahan kering seperti tepung disimpan pada suhu $25^{\circ} \mathrm{c}$ atau suhu ruangan.

Pengelola warung makan sebaiknya melakukan pemilahan bahan mentah yang akan disimpan ke dalam lemari pendingin terlebih dahulu. Untuk menghindari terjadinya pembusukan atau kontaminasi pada bahan yang akan diolah.

\section{Pengolahan Bahan Makanan Mentah menjadi Makanan Jadi}

Pengolahan makanan merupakan proses merubah bentuk dari bahan mentah menjadi makanan siap saji. Pengolahan makanan harus dilakukan dengan cara yang baik menggunakan sarung tangan, penjeit makanan sehingga terlindung dari kontak langsung dengan tubuh (Arisman, 2009).

Berdasarkan hasil observasi yang dilakukan peneliti, proses pengolahan bahan makanan dalam proses memasak dari 8 warung yang ada memiliki waktu yang berbeda. Pada warung pertama aktivitas memasak di lakukan rata-rata dilakukan pada dini hari dan sebelum subuh. Sebelum dilakukan proses memasak bahan-bahan 
dikeluarkan dari dalam kulkas terlebih dahulu, lalu bahan-bahan yang membeku seperti ayam,ikan dan daging dikeluarkan lebih dulu sebelum waktu memasak dimulai. Bahan makanan seperti sayursayuran dipilih, dipotong lalu dicuci sebelum dimasak.

Semua bahan-bahan mentah yang akan dimasak melalui proses pencucian dengan air mengalir dan dicuci secara berulang untuk memastikan tidak adanya kotoran yang akan hinggap lagi di bahan makanan tersebut. Pada proses memasak, bahan makanan yang di masak pertama seperti ikan maupun ayam. Kedua bahan makanan tersebut lalu dibumbui dengan bumbu yang sudah diracik. Persiapan sebelum mengolah makanan sudah cukup baik dan proses memasak juga sudah memenuhi syarat dengan menggunakan kuali dan kompor gas.

Penelitian ini sejalan dengan penelitian Kuncoroputri (2012) di Catering X, Y dan $\mathrm{Z}$ Purworejo, Jawa Tengah. Berdasarkan penelitian nya pengolahan makanan di Catering $\mathrm{X}, \mathrm{Y}$ dan $\mathrm{Z}$ sebagian besar telah sesuai dengan kriteria standar yang berlaku. Penanganan sayuran, buah-buahan, ikan, ayam, daging dan sejenisnya sebelum dilakukannya proses memasak melalui proses pencucian bahan makanan dengan menggunakan air mengalir. Proses memasak yang dilakukan pertama di masing-masing catering dengan memasak goreng-gorengan terlebih dahulu lalu masakan berkuah dimasak paling akhir.

Proses pengolahan bahan makanan menjadi makanan jadi telah melalui tahapan memenuhi syarat, dari pencucian, pemotongan dan proses memasak. Dalam proses pengolahan makanan ini, harus selalu memperhatikan, mempertahankan serta meningkatkan proses pengolahan makanan agar kualitas makanan tetap terjaga dan tidak terjadinya kontaminasi makanan yang akan disajikan.

\section{Peralatan Makanan}

Kebersihan peralatan makanan merupakan salah satu faktor yang harus diperhatikan, karena peralatan makanan atau masak yang tidak bersih dapat menyebabkan kotaminasi silang. Menurut Permenkes No. 1096/Menkes/Per/VI/2011 peralatan makan dan peralatan masak harus terbuat dari bahan tara pangan (Food Grade), lapisan permukaan peralatan makan tidak mengeluarkan bahan berbahaya sera logam beracun dan perlengkapan pengolahan seperti kompor, tabung gas harus berfungsi dengan baik sehingga tidak menyebabkan sumber bencana.

Berdasarkan hasil observasi yang dilakukan peneliti, peralatan yang digunakan untuk memasak dan menyajikan makanan seperti kuali, piring, gelas, sendok dalam keadaan rak-rak dengan kondisi terbuka, kuali di gantung-gantung begitu saja sehingga bisa terjadi penempelan debu dan adanya serangga maupun binatang pengganggu. Menurut wawancara mendalam yang dilakukan informan dari 8 warung yang ada mencuci peralatan sebelum digunakan untuk memasak, tetapi pada hasil pengamatan tidak dilakukannya pencucian peralatan saat akan digunakan untuk memasak. Peralatan dicuci hanya setelah proses memasak selesai dilakukan.

Hal ini sejalan dengan penelitian Reinanda (2018) di Dapur Umum Panti Asuhan Al Istiklal Kota Pekanbaru. Berdasarkan hasil penelitiannya peralatan dan perlengkapan di dapur umum panti seperti kuali, rak-rak yang berisi gelas, piring, mangkok dan peralatan masak terletak di luar ruangan dalam kondisi yang terbuka sehingga memungkinkan terkontaminasinya bakteri dan binatang penggangu seperti tikus, serangga dan sejenisnya.

Pada penelitian Sakriani (2016) juga diketahui bahwa $48 \%$ rumah makan yang diteliti termasuk peralatan makan dengan higiene sanitasi yang rendah. Sehingga berpotensi untuk terkontaminasi. Peralatan makan selalu kotor. Alat makan yang kotor dapat disebabkan oleh kondisi alat, apakah mudah dibersihkan atau tidak mudah dibersihkan. 
Hal serupa juga ditemukan pada penelitian Isnadi (2018) dimana ditemukan sebanyak $67 \%$ peralatan makan di Kantin di salah satu Universitas di Sumatera Utara terkontaminasi bakteri. Seluruh penyedia makanan belum memiliki tempat pencucian peralatan yang terpisah dengan pencucian bahan makanan, dan belum dicuci dengan sebagaimana mestinya, baik dari segi pencucian dan peralatan cuci yang bersih.

Peralatan dalam mengolah masakan dan makanan harus dijaga kebersihan dan kerapian nya. Pada Warung Makan Pasar Cik Puan Pekanbaru masih belum memenuhi persyaratan dikarenakan rak-rak penyimpanan yang masih terbuka sehingga dapat terjadinya kontaminasi debu dan binatang pengganggu. Pihak warung harus memperhatikan kebersihan dan kerapian peralatan sebelum digunakan untuk mengolah makanan dan menyediakan makanan.

\section{Penyimpanan Makanan Jadi}

Berdasarkan Peraturan Menteri Kesehatan Nomor 1096/Menkes/ Per/VI/2011 makanan jadi/masak tidak boleh rusak, tidak basi yang menimbulkan rasa bau, berlendi, berubah warna dan berjamur. Wadah penyimpanan harus terpisah untuk setiap jenis makanan jadi serta mempunyai tutup yang dapat menutup sempurna. Makanan jadi/masak harus terpisah dengan bahan makanan mentah.

Berdasarkan hasil observasi dapat dilihat bahwa makanan yang telah jadi pada warung pertama diletakan begitu saja masih dalam kuali dalam keadaan yang ditutup, pada warung kedua, makanan ditempatkan diwadah stainless dalam keadaan terbuka begitu saja. Sedangkan pada warung yang ketiga makanan berkuah, seperti kuah soto diletakkan begitu saja bersebelahan dengan tempat gantungan plastik bekas kemasan minuman, dalam kondisi dibiarkan terbuka. Kondisi tersebut dapat menyebabkan makanan tercemar atau tidak terjaganya kebersihan dari makanan yang telah jadi. Makanan yang tidak tertutup dapat menyebabkan risiko dihinggapinya binatang pengganggu seperti lalat yang dapat menyebabkan terjadinya gangguan kesehatan tubuh.

Idealnya penyimpanan bahan

makanan disimpan pada tempat penyimpanan dalam keadaan tertutup (Hitipeuw, 2018). Sejalan dengan penelitian Kuncoroputri (2012) di Catering $\mathrm{X}, \mathrm{Y}$ dan $\mathrm{Z}$ Purworejo, Jawa Tengah. Berdasarkan penelitiannya dari 3 catering yang dilakukan pengamatan untuk makanan yang sudah jadi mendapat perlakuan yang berbeda. Pada catering $\mathrm{X}$ makanan diletakkan di wadah terpisah dan ditutup, namun tidak ditutup rapat sehingga udara panas dapat keluar. Catering $\mathrm{Y}$ biasanya makanan yang sudah masak tetap berada di wajan dan panci kemudian di letakkan diatas penyangga. Sedangkan Catering $\mathrm{Z}$ makanan yang telah masak langsung diletakkan di wadah dan diletakan di atas meja.

Penyimpanan makanan jadi yang akan disediakan untuk konsumen masih belum memenuhi syarat. Dalam pengamatan yang terjadi pihak warung masih belum menutup makanan dengan baik, sehingga kemungkinan adanya kontaminasi dari debu dan binatang pengganggu seperti lalat hinggap pada makanan. Pihak warung sebaiknya memperhatikan penyimpanan makanan seperti mmenggunakan wadah dan penutup yang rapat agar selalu terjaga kebersihan makanan yang akan dijual kepada konsumen.

\section{Penyajian Makanan}

Penyajian makanan merupakan hal terakhir yang dilakukan dalam proses perjalanan makanan. Makanan yang disajikan harus bersih, tertutup dan bebas dari adanya kontaminasi. Berdasarkan hasil observasi yang dilakukan peneliti dalam penyajian makanan, Pada warung makanan berkuah seperti lontong, soto, miso dan sate disajikan selalu dalam keadaan panas. Dari hasil wawancara terhadap informan makanan diwarung yang masih tersisa akan dikonsumsi sendiri oleh pemilik warung, 
tidak adanya pemanasan lauk untuk dijual dihari berikutnya. Penyajian makanan untuk konsumen menggunakan piring dan mangkok yang telah cukup memenuhi syarat, penyajian makanan menggunakan peralatan yang bersih.

Berdasarkan penelitian Sari,dkk. (2012) penyajian makanan disajikan diatas meja dengan keadaan tertutup. Meja harus dibersihkan sebelum makanan di letakkan diatas meja dan peralatan makanan harus dalam keadaan bersih. Serta Reinanda (2018) di Dapur Umum Panti Asuhan Al Istiklal Kota Pekanbaru, penyajian makanan diletakkan pada tempat mangkok stainless yang bersih, setelah itu makanan dimasukkan ke dalam wadah yang tertutup dan penyajian makanan tidak pernah

\section{KESIMPULAN}

Berdasarkan hasil penelitian yang dilakukan pada Warung Makan di Pasar Cik Puan Pekanbaru terhadap penerapan higiene sanitasi makanan dapat disimpulkan bahwa proses Pemilihan bahan makanan mentah, proses pengolahan makanan, dan penyajian di 8 Warung Makan di Pasar Cik Puan Pekanbaru telah memenuhi persyaratan higiene sanitasi makanan. Dan Penyimpanan bahan makanan mentah, peralatan masak dan makan, dan penyimpanan bahan makanan, di 8 Warung Makan di Pasar Cik Puan Pekanbaru masih belum memenuhi syarat higiene sanitasi makanan yang tertera pada Permenkes No. 1096/Menkes/ Per/VI/2011.

\section{UCAPAN TERIMAKASIH}

Kami ucapkan terimakasih kepada Yayasan Tuah Pekanbaru, Unit Penelitian dan Pengabdian kepada Masyarakat STIKes Hang Tuah Pekanbaru yang telah mendanai kegiatan penelitian ini. Serta pemilik warung makan di Pasar Cik Puan yang telah berkenan menjadi responden kami dan pihak-pihak terkait yang tidak dapat kami sebutkan satu persatu, memanaskan makanan secara berulangulang.

Penelitian ini juga sejalan dengan Kuncoroputri (2012) di Catering X, Y dan $\mathrm{Z}$ Purworejo, Jawa Tengah. Berdasarkan penelitian nya 3 catering tersebut penyajian makanan yang akan disajikan menggunakan sendok, penjepit, atau pun menggunakan tangan yang terbungkus plastik untuk memegang makanan dan tidak kontak langsung dengan tangan penjamah.

Pelaksanaan higiene sanitasi yang baik akan dipengaruhi oleh pengetahuan pengelola warung makan sehingga dapat tercipta sanitasi lingkungan yang memenuhi syarat.

terimakasih atas bantuan dalam penyelesaian penelitian ini.

\section{DAFTAR PUSTAKA}

Arisman. (2009). Buku Ajar Ilmu Gizi Keracunan Makanan. Penerbit Buku Kedokteran EGC. Jakarta.

Badan Pengawasan Obat dan Makanan. (2018). Laporan Tahunan Badan POM 2017. Badan POM. Jakarta.

Dakwani, Tifal. (2019). Higiene Sanitasi Tempat Pengelolaan Makanan (TPM) di Gudang 100 pada Pelabuhan Laut Tanjung Perak Surabaya.Tahun 2018. Jurnal Kesehatan Lingkungan Vol. 11 No. 1 Januari 2019 (69 - 74). DOI: 10.20473/jkl.v11i1. 2019.69-74 ISSN: 1829 - 7285 E-ISSN: 2040 $881 \mathrm{X}$

Depkes RI, (2011). Keputusan Menteri Kesehatan RI No. 1096/MENKES/SK/PERVI/2011

Tentang Higiene Sanitasi Jasa Boga. Jakarta. Departemen Kesehatan.

Depkes RI, (2009). Sistem Kesehatan Nasional. Jakarta.

Hitipeuw. M.R.C, dkk.(2018). Higiene dan Sanitasi Rumah Makan di Kompleks 
Wanea Plaza Kota Manado. Jurnal KESMAS, Volume 7 Nomor 4

Isnadi $\mathrm{Y}$, Malaka $\mathrm{T}$, Dahlan $\mathrm{H}$, Novrikasari. (2018). Food higiene and sanitation in six food providers at University $X$, South Sumatra. Kesmas: National Public Health Journal. 2018; 12 (4): 194-201. (doi:10.21109/kesmas.v12i4.1414)

Kesuma, I Wayan A.W.A, dkk. (2018). Aspek Sanitasi dan Higiene di Warung Makan Ikan Laut Kawasan Pantai Lebih Kabupaten Gianyar. Jurnal Rekayasa dan Manajemen Agroindustri. Vol. 6, No.4, 356-364, Desember 2018. ISSN : 2503-488X

Kuncoroputri, Kartika, A. (2012). Studi Kualitatif Mengenai Gambaran Penerapan Food Safety pada Usaha Jasaboga Informal di Catering $\mathrm{X}$, Y, dan Z Purworejo, Jawa Tengah. Program Sarjana Kesehatan Masyarakat. Universitas Indonesia.

Mundiatun, Daryanto. (2015). Pengelolaan Kesehatan Lingkungan

Yogyakarta.Gava Media.

Rahmadiyanti, Nannissa Hidayah. 2018. Penerapam Higiene Sanitasi di Warung Makan Pasar Ngasem sebagai penunjang wisata kuliner Kota Yogyakarta. Jurnal Pendidikan Teknik Boga Vol.7 No.5, Pendidikan Teknik Boga Universitas Negeri Yogyakarta

Reinanda, Dea, P. (2018). Penerapan Higiene dan Sanitasi Pengelolaan Makanan di Dapur Umum Panti Asuhan Al-Istiklal Kota Pekanbaru. Program Studi Kesehatan Masyarakat STIKes Hang Tuah, Pekanbaru.

Sakriani, Sidebang. (2016). Gambaran Higiene Sanitasi Pengolahan Makanan di Rumah Makan yang Ada di Wilayah Kerja Puskesmas Kota. Jurnal Kesehatan Poltekkes Ternate, 9(1),2016, pages 6-10

Septiani, P.C, Wulandari R.A., (2020). Gambaran Higiene Sanitasi
Makanan dan Penerapan Prinsip Hazard Analysis Critical Control Point (HACCP) di Unit Instalasi Gizi Rumah Sakit X Tahun 2018. Jurnal Nasional Kesehatan Lingkungan Global: Volume 1, Issue 1

Sukmadewi, N.L.U, Puspaningrum D.H.D. (2018). Program Peningkatan Higiene dan Sanitasi Pada Warung Makan Nasi Ayam Betutu di Banjar Cengkok, Desa Baha, Kecamatan Mengwi Kabupaten Badung Bali. Jurnal Paradharma 2(1): 39 - 42 ISSN : 2549-7405

Syahlan, V. L. G., WoodFord, B. S. J. dan Oksfriani, J. S. (2018). Higiene Sanitasi Pengelolaan Makanan dan Angka Kuman Peralatan Makan (Piring) di Instalasi Gizi Rumah Sakit Umum Pancaran Kasih GMIM Kota Manado. Jurnal KESMAS. $7(5)$.

WHO. (2020). Food Safety. Diakses pada 08 Februari 2021 https://www. who.int / NEWS-ROOM / FACTSHEETS/DETAIL/ FOOD-SAFETY

Yunus, S, (2015). Hubungan Personal Higiene dan Fasilitas Sanitasi dengan Kontaminasi Escherichia Coli Pada Makanan Di Rumah Makan Padang Kota Manado Dan Kota Bitung. Manado. Jurnal Ilmu Kesehatan Masyarakat Vol. 5, No. 2. Universitas Sam Ratulangi. Manado 